\title{
Prenatal androgen excess enhances stimulation of the GNRH pulse in pubertal female rats
}

\author{
Xiaonan Yan ${ }^{1,2}$, Chun Yuan', Nannan Zhao', Yugui Cui ${ }^{1}$ and Jiayin Liu' \\ ${ }^{1}$ State Key Laboratory of Reproductive Medicine, Clinical Center of Reproductive Medicine, First Affiliated Hospital, \\ Nanjing Medical University, 300 Guangzhou Road, Nanjing 210029, China \\ ${ }^{2}$ Xuzhou Medical College, Clinical Center of Reproductive Medicine, First Affiliated Hospital, Xuzhou 221000, China
}

Correspondence should be addressed

to J Liu

Email

jyliu_nj@126.com

\begin{abstract}
In adolescent girls with polycystic ovary syndrome (PCOS), neuroendocrine derangements manifest after the onset of puberty, characterized by rapid LH pulse frequency. The early mechanism underlying the pubertal regulation of the $\mathrm{GNRH} / \mathrm{LH}$ pulsatile release in adolescents with PCOS remains uncertain. To determine the effects of prenatal androgen exposure on the activation of GNRH neurons and generation of LH pulse at puberty, we administrated $5 \alpha$-dihydrotestosterone to pregnant rats and observed serum LH levels and expression of hypothalamic genes in female offspring from postnatal 4 to 8 weeks. The 6-week-old prenatally androgenized (PNA) female rats exhibited an increase in LH pulse frequency. The hypothalamic expression of neurokinin B (Nkb (Tac2)) and Lepr mRNA levels in PNA rats increased remarkably before puberty and remained high during puberty, whereas elevated Kiss1 mRNA levels were detected only after the onset of puberty. Exogenous kisspeptin, NK3R agonist, and leptin triggered tonic stimulation of GNRH neurons and increased LH secretion in 6-week-old PNA rats. Leptin upregulated Kiss1 mRNA levels in the hypothalamus of pubertal PNA rats; however, pretreatment with a kisspeptin antagonist failed to suppress the elevated serum LH stimulated by leptin, indicating that the stimulatory effects of leptin may be conveyed indirectly to GNRH neurons via other neural components within the GNRH neuronal network, rather than through the kisspeptin-GPR54 pathway. These findings validate the hypotheses that NKB and leptin play an essential role in the activation of GNRH neurons and initiation of increased LH pulse frequency in PNA female rats at puberty and that kisspeptin may coordinate their stimulatory effects on LH release.
\end{abstract}

\footnotetext{
Key Words

- androgen

- puberty

- gonadotropin-releasing hormone

- neurokinin B

- kisspeptin

- leptin

- polycystic ovary syndrome
}

Journal of Endocrinology (2014) 222, 73-85

\section{Introduction}

Polycystic ovary syndrome (PCOS) is a complex multifactorial disorder characterized by oligo-ovulation or anovulation, hyperandrogenism, polycystic ovaries, luteinizing hormone (LH) hypersecretion, and insulin resistance. Clinical, experimental, and genetic evidence supports the hypothesis that prenatal exposure to excessive maternal androgens induces the PCOS-related phenotype in female offspring (Xita \& Tsatsoulis 2006, Forsdike et al. 2007, Abbott et al. 2009, Roland et al. 2010, Tyndall et al. 2012). Prenatal androgen excess resets the reproductive and metabolic trajectory of the growing fetus and reprograms target tissue differentiation and development, resulting in the development of PCOS in adolescents and adults (Franks 2012). Peripubertal reproductive and metabolic

Published by Bioscientifica Ltd 
dysfunctions, including anovulation, hyperandrogenism, insulin resistance, and hyperinsulinemia, are present in adolescents with PCOS before the onset of puberty and persist during pubertal development (Huang et al. 2010). The significant overlap between these symptoms and the normal physiological changes associated with puberty mean that PCOS is possibly being under-evaluated in the adolescent population, raising serious concerns over the potential and extended public health consequences (Broder-Fingert et al. 2009). Therefore, a better understanding of the pathogenesis of PCOS in adolescents may be key for minimizing the development of symptoms and for preventing the onset of the long-term complications associated with this syndrome.

The activation of gonadotropin-releasing hormone (GNRH) neurons and the establishment of pulsatile GNRH secretion during late postnatal development are essential for initiating the process of puberty (Terasawa \& Fernandez 2001). On the basis of the ability of mutations or deletion of the kisspeptin receptor ( $G$ protein-coupled receptor, GPR54 (KISS1R)) to cause hypogonadotropic hypogonadism and prevent normal pubertal maturation in humans and animal models, compelling evidence indicate that kisspeptinGPR54 signaling activates the GNRH neurons and triggers the onset of puberty (Clarkson et al. 2010). Further studies demonstrated that exogenous kisspeptin potently stimulated GNRH-dependent LH secretion before puberty in both primates and rodents, supporting the hypothesis that kisspeptin has a critical role in GNRH/LH pulsatile release and normal pubertal maturation (Navarro et al. 2004, Plant et al. 2006). Recent studies have shown that mutations of the genes encoding either neurokinin $B(N K B)$ or its cognate receptor (NK3R) resulted in hypogonadotropic hypogonadism, similar to mutations of the kisspeptin system (Guran et al. 2009, Topaloglu et al. 2009). Pulsatile administration of GNRH to adults with $N K B$ or NK3R gene mutations restored serum LH and testosterone secretion in males and resulted in ovulation, pregnancy, and a normal birth in a female (Young et al. 2010). These data implicate NKB signaling as an essential component for the onset of puberty and the control of GNRH release. However, the effects of NKB on the regulation of GNRH/LH secretion remain controversial in humans and animal models. In the ewe, activation of NK3R with senktide, a potent and selective NK3R agonist, consistently stimulates LH secretion (Billings et al. 2010). In contrast to humans and sheep, senktide suppressed LH secretion in rats (Sandoval-Guzman \& Rance 2004) and mice (Castellano et al. 2009).

In 2007, both NKB and kisspeptin, along with dynorphin (DYN), were shown to be colocalized in a single subpopulation in the arcuate nucleus (ARC) of the sheep (Goodman et al. 2007). Further studies demonstrate that a subset of neurons colocalizing kisspeptin, NKB, and DYN in the ARC, abbreviated as the KNDy subpopulation, are strongly conserved across multiple mammalian species, from rodents to humans, and are part of the neural network modulating pulsatile GNRH secretion. On the basis of further observations, researchers have speculated that kisspeptin stimulates and DYN inhibits GNRH pulses; however, the actions of NKB remain controversial. These data raise the possibility that dysfunctional coordination of the KNDy network may underlie neuroendocrine defects in clinical reproductive disorders, including PCOS (Lehman et al. 2010). Adolescents with PCOS show disruption in the regulation of the GNRH pulse generator, characterized by rapid LH pulse frequency (Burt Solorzano et al. 2010). To date, the limited investigations have focused on the early neurobiological mechanisms underlying pubertal regulation of the GNRH/LH pulsatile release by kisspeptin and NKB in adolescents with PCOS.

The aim of this study was to determine the effect of intrauterine androgen exposure on LH secretion and the role of kisspeptin and NKB neurons in the alteration of GNRH/LH pulsatile secretion in female offspring of androgen-exposed rats at peripubertal stage. The levels of serum LH and expression of hypothalamic genes in prenatally androgenized (PNA) female rats were observed at postnatal weeks 4,6 , and 8 . Through i.c.v. administration, we investigated whether the resulting neuroendocrine derangements could be attributed to the modulation of kisspeptin and NKB neurons in the hypothalamic ARC of PNA rats. We also elucidated the interaction of kisspeptin, NKB, and leptin on the regulation of pulsatile GNRH/LH secretion at puberty.

\section{Materials and methods}

\section{Animals}

Both female and male Sprague-Dawley rats were purchased from the Lab Animal Center of Nanjing Medical University and animal care was conducted in accordance with the Animal Research Committee Guidelines of Nanjing Medical University. The rats were housed at $25^{\circ} \mathrm{C}$ under a $12 \mathrm{~h}$ light: $12 \mathrm{~h}$ darkness cycle, with a humidity of $65-70 \%$. Water and food were available and animals were allowed to eat and drink ad libitum. The Institutional Ethics Committee of Nanjing Medical University approved all the experimental procedures.

Female rats were mated with males overnight and copulatory plugs were examined the next morning. The

Published by Bioscientifica Ltd. 
day on which copulatory plugs were verified was arbitrarily considered as day 1 of gestation. On days 16-19 of gestation, the rats received s.c. injections of either $5 \mathrm{mg} /$ day $5 \alpha$-dihydrotestosterone (DHT; Dr. Ehrenstorfer $\mathrm{GmbH}$, Augsburg, Germany) dissolved in $500 \mu \mathrm{l}$ sesame oil (Sigma)/benzyl benzoate (Sigma) (DHT, $n=30$ ) or a vehicle as a control $(\mathrm{C}, n=24)$. The dose of DHT was selected on the basis of previous experiments (Foecking et al. 2005, Yan et al. 2013). All litters were weaned and females were separated from males at 21 days of age. Female offspring were observed from 4 weeks (prepuberty) to 8 weeks (late puberty) (Fig. 1).

\section{Experimental design}

Experiment 1: measurement of serum LH in PNA rats At postnatal weeks 4,6 , and 8 blood samples were collected by orbital puncture after the rats were fasted overnight and anesthetized with pentobarbital sodium at $0800 \mathrm{~h}$. In addition, to determine whether prenatal androgen excess induced the increased LH pulse frequency in female rats at puberty, 6-week-old PNA $(n=8)$ and control rats $(n=7)$ were anesthetized and blood samples were taken by jugular venipuncture every $10 \mathrm{~min}$ for $3 \mathrm{~h}$ (between 0800 and $1100 \mathrm{~h})$. After each blood sample was drawn (100 $\mu \mathrm{l})$, an equal volume of heparinized saline ( $25 \mathrm{U}$ heparin sodium $/ \mathrm{ml}$ normal saline) was infused. The sera were stored at $-80{ }^{\circ} \mathrm{C}$ until LH measurement.
Experiment 2: effect of prenatal androgen excess on expression of hypothalamic genes in PNA rats To analyze whether prenatal androgen exposure influenced the expression of genes associated with the regulation of GNRH/LH secretion in the hypothalamus of female rats during peripubertal development, the mRNA levels of Kiss1, Kiss1r, Nkb, Nk3r (Tacr3), Npy, Npyr (Npy1r), Lepr, Gnrh (Gnrh1), Agrp, and Pomc were evaluated in hypothalamic samples from peripubertal PNA rats. At the ages of 4,6 , and 8 weeks the female rats were decapitated and their hypothalamuses were immediately dissected, as described previously (Quennell et al. 2011). The hypothalamic samples were frozen in liquid nitrogen and stored at $-80^{\circ} \mathrm{C}$ until RNA analysis.

Experiment 3: coexpression of kisspeptin/LEPR and NKB/LEPR in the hypothalamic ARC of PNA rats This experiment was intended to determine whether kisspeptin and NKB neurons in the hypothalamic ARC of pubertal female rats coexpress the leptin receptor. The 6-week-old PNA $(n=6)$ and control rats $(n=6)$ were anesthetized and perfused with ice-cold normal saline, followed by $4 \%$ paraformaldehyde for brain collection. Brains were removed from the skulls, postfixed overnight in $4 \%$ paraformaldehyde, and transferred gradually into 20 and $30 \%$ sucrose until settled. Coronal sections ( $40 \mu \mathrm{m}$ thick) throughout the ARC were cut from each brain on a freezing microtome (Leica, Nussloch, Germany) for immunofluorescence staining.

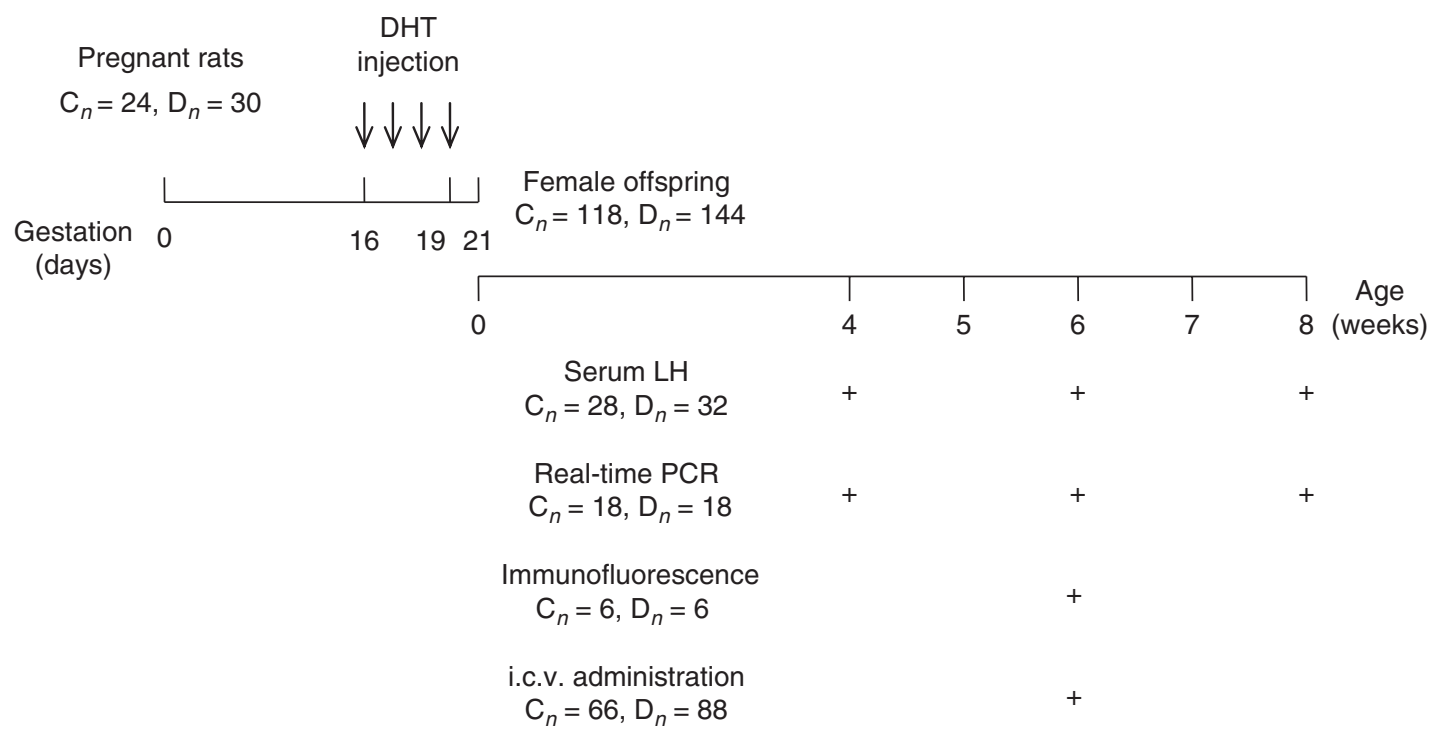

Figure 1

Study schema with the number of animals used in each experiment. $C_{n}$, number of control rats; $\mathrm{D}_{n}$, number of rats treated prenatally with DHT; DHT, $5 \alpha$-dihydrotestosterone.

http://joe.endocrinology-journals.org DOI: 10.1530/JOE-14-0021
() 2014 Society for Endocrinology Printed in Great Britain
Published by Bioscientifica Ltd. 
Experiment 4: effects of central administration of kisspeptin, senktide, and leptin on $\mathrm{LH}$ secretion in pubertal PNA rats This experiment was intended to assess whether i.c.v. administration of kisspeptin, senktide, or leptin affected serum LH secretion in pubertal PNA rats. The 5-week-old female rats were anesthetized and an i.c.v. infusion cannula (RWD Life Science, Shenzhen, China) was implanted in the lateral cerebral ventricle. The insertion point was $1.5 \mathrm{~mm}$ lateral and $1 \mathrm{~mm}$ posterior to bregma and $4.0 \mathrm{~mm}$ below the surface of the skull. The animals were allowed to recover for 7 days. The PNA $(n=16)$ and control groups $(n=16)$ were equally divided and received i.c.v. injections of kisspeptin ( $1 \mathrm{nmol} / 10 \mu \mathrm{l}$, Phoenix Pharmaceuticals, Belmont, CA, USA) or vehicle (10 $\mu 10.9 \%$ sodium chloride) respectively. The dose concentration of kisspeptin was selected on the basis of previous studies that reported that this dose potently elicited $\mathrm{LH}$ secretion in rats (Castellano et al. 2006, 2009). Blood samples were collected by jugular venipuncture before $(0 \mathrm{~min})$ and 15,30 , and $60 \mathrm{~min}$ after kisspeptin injection. The sera were stored at $80{ }^{\circ} \mathrm{C}$ until $\mathrm{LH}$ measurement. Central administration of senktide (600 pmol/10 $\mu \mathrm{l}$, Sigma) and leptin ( $1 \mathrm{nmol} / 10 \mu \mathrm{l}$, Sigma) was conducted in the animals and sera were collected, following protocols similar to those for kisspeptin administration. The doses of senktide and leptin were selected on the basis of previous studies (Roa et al. 2008, Navarro et al. 2012). The integrated LH secretory responses were expressed as the area under the curve (AUC) over a 60 min period after the administration.

Experiment 5: effects of central administration of kisspeptin, senktide, and leptin on expression of hypothalamic genes in pubertal PNA rats This experiment was intended to explore whether the interaction of kisspeptin, $\mathrm{NKB}$, and leptin was responsible for the impaired regulation of GNRH/LH secretion in PNA rats at puberty. The 5-week-old female rats had an i.c.v. infusion cannula implanted, as described for experiment 4 . One week later, the PNA $(n=18)$ and control rats $(n=18)$ were decapitated 30 min after central administration of kisspeptin, senktide, or leptin. The hypothalamus was immediately dissected, frozen in liquid nitrogen, and stored at $-80^{\circ} \mathrm{C}$ until RNA analysis.

Experiment 6: effect of leptin on serum LH secretion in pubertal PNA rats pretreated with a kisspeptin antagonist To investigate whether leptin stimulates LH secretion indirectly by activating the ARC kisspeptin neurons at puberty, 6-week-old PNA rats were pretreated with a kisspeptin receptor antagonist (kisspeptin-234) and then serum LH levels were evaluated after administration of leptin. The 5-week-old PNA rats had an i.c.v. infusion cannula, implanted as described for experiment 4 . One week later, the PNA rats $(n=8)$ were treated with kisspeptin234 ( 2 nmol/5 $\mu$ l, Tocris Bioscience, Bristol, UK) over 5 min, followed by leptin ( $1 \mathrm{nmol} / 5 \mu \mathrm{l}) 10 \mathrm{~min}$ later. Negative control rats $(n=7)$ were pretreated with kisspeptin-234 followed by vehicle ( $5 \mu \mathrm{l} 0.9 \%$ sodium chloride); positive control rats $(n=7)$ received vehicle before leptin treatment.

\section{Measurement of serum LH}

The serum LH concentrations were measured using commercial rat LH ELISA Kits (Shibayagi Co. Ltd, Gunma, Japan), according to the manufacturer's recommendations. The sensitivity of the LH assay was $0.313 \mathrm{ng} / \mathrm{ml}$. The intraand inter-assay coefficients of variation were $<5 \%$.

\section{RNA analysis by real-time PCR}

The real-time PCR was conducted using a slight modification of a previously described method (Li et al. 2010). Total RNA was isolated from hypothalamic samples using TRIzol reagent (Invitrogen) and $1 \mu \mathrm{g}$ RNA from each rat was reverse-transcribed into cDNA. The primers used for the assessment of hypothalamic genes are listed in Table 1 . The nucleotide sequences for these genes were designed using Primer Premier 5.0 Software (Premier Biosoft International, Palo Alto, CA, USA) and based on NCBI rat reference sequences. The primers were synthesized commercially by Invitrogen. $\beta$-actin was used as the internal standard. The final reaction mixture contained $1 \mu \mathrm{l}$ cDNA, 10 pmol each forward and reverse primer, $0.4 \mu \mathrm{l}$ ROX reference dye, and $10 \mu \mathrm{l}$ SYBR Premix Ex Taq (Takara Bio, Dalian, China) in a total reaction volume of $20 \mu$ l. The PCR conditions for the genes, except for $N k b$, were $95^{\circ} \mathrm{C}$ for $1 \mathrm{~min}$, followed by 40 cycles of $95^{\circ} \mathrm{C}$ for $15 \mathrm{~s}$ and $60{ }^{\circ} \mathrm{C}$ for $1 \mathrm{~min}$. The amplification conditions for $\mathrm{Nkb}$ were $95^{\circ} \mathrm{C}$ for $1 \mathrm{~min}$, followed by 40 cycles of $95^{\circ} \mathrm{C}$ for $15 \mathrm{~s}, 60^{\circ} \mathrm{C}$ for $15 \mathrm{~s}$, and $72^{\circ} \mathrm{C}$ for $15 \mathrm{~s}$. Quantitative analysis of genes was carried out using the StepOnePlus Real-Time PCR System and StepOne Software v2.1 (Applied Biosystems) according to the recommendations of the manufacturer.

\section{Double-label immunofluorescence}

Free-floating sections were collected, rinsed with PBS, and preincubated with blocking solution (10\% donkey serum) for $60 \mathrm{~min}$ at $37^{\circ} \mathrm{C}$. The sections were then incubated with a solution containing chicken anti-leptin receptor antibody (Abcam, Inc., Cambridge, MA, USA) and either

Published by Bioscientifica Ltd. 
Table 1 The primers used for assessment of hypothalamic genes by real-time PCR

\begin{tabular}{|c|c|c|c|}
\hline Gene & Primer sequence $\left(5^{\prime}-3^{\prime}\right)$ & Product size (bp) & GenBank accession no. \\
\hline Kiss1 & & 152 & NM_181692 \\
\hline Forward & AGCTGCTGCTTCTCCTCTGT & & \\
\hline Reverse & AGGCTTGCTCTCTGCATACC & & \\
\hline Kiss1r & & 222 & NM_023992 \\
\hline Forward & GCAGACCGTCACCAATTTCT & & \\
\hline Reverse & GGGAACACAGTCACGTACCA & & \\
\hline$N k b$ & & 101 & NM_019162 \\
\hline $\begin{array}{l}\text { Forward } \\
\text { Reverse }\end{array}$ & $\begin{array}{l}\text { GAGGAACAGCCAACCAGACA } \\
\text { GAGTGGAGTGCTTTTCTGCAC }\end{array}$ & & \\
\hline$N k 3 r$ & & 111 & NM_017053 \\
\hline Forward & AGCAGCTGAAGGCTAAACGA & & \\
\hline Reverse & GGTAGATCGCAGTGAGAATGAA & & \\
\hline Npy & & 98 & NM_012614 \\
\hline Forward & AGAGATCCAGCCCTGAGACA & & \\
\hline Reverse & TCACCACATGGAAGGGTCTT & & \\
\hline Npyr & & 89 & NM 001113357 \\
\hline Forward & ACGTTCGCTTGAAAAGGAGA & & \\
\hline Reverse & CATGACGTTGATTCGTTTGG & & \\
\hline Lepr & & 185 & NM_012596 \\
\hline Forward & СССССАСТGAAAGACAGCTT & & \\
\hline Reverse & GGCTTCACAACAAGCATGGG & & \\
\hline Gnrh & & 150 & NM_012767 \\
\hline Forward & CCGCTGTTGTTCTGTTGACTGTG & & \\
\hline Reverse & GGGGTTCTGCCATTTGATCCTC & & \\
\hline Agrp & & 76 & NM_033650 \\
\hline Forward & AAGCTTTGGCAGAGGTGCTA & & \\
\hline Reverse & GACTCGTGCAGCCTTACACA & & \\
\hline Pomc & & 76 & NM_139326 \\
\hline Forward & TCCTCAGAGAGCTGCCTTTC & & \\
\hline Reverse & CCTGAGCGACTGTAGCAGAA & & \\
\hline$\beta$-actin & & 191 & NM_031144 \\
\hline Forward & TGCCGCATCCTCTTCCTC & & \\
\hline Reverse & GGTCTTTACGGATGTCAACG & & \\
\hline
\end{tabular}

rabbit anti-kisspeptin antibody (Merck Millipore, Billerica, MA, USA) or rabbit anti-NKB antibody (Phoenix Pharmaceuticals) for $24 \mathrm{~h}$ at $4{ }^{\circ} \mathrm{C}$. Then, the sections were washed again with PBS and incubated with donkey anti-chicken antibody conjugated to Alexa Fluor 488 (Jackson Immunoresearch Laboratories, Inc., West Grove, PA, USA) and donkey anti-rabbit antibody conjugated to Alexa Fluor 555 (Invitrogen) for $30 \mathrm{~min}$ at $37^{\circ} \mathrm{C}$. After further washes, freefloating sections were mounted on slides and cover slips were applied. The images were taken using a Zeiss LSM 710 laser-scanning confocal microscope (Carl Zeiss, Jena, Germany) and analyzed using ZEN 2011 Image Software (Carl Zeiss). The numbers of single- and double-labeled neurons were counted in four sections that contained the caudal portion of the ARC in each animal by two persons blinded to the origin of the sections.

\section{Statistical analysis}

The serum LH pulses were analyzed using the PULSAR Analysis Software (Mostari et al. 2013). The effects of DHT on serum LH and hypothalamic genes expression at the same development stage were analyzed by two-tailed Student's $t$-tests. In the 6-week-old PNA and control rats treated with kisspeptin, senktide, or leptin, serum LH values from the treatment groups and vehicle groups were compared at each time point using repeated measures ANOVA. The 0- to 60-min AUC for the integrated $\mathrm{LH}$ secretory responses after central administration was analyzed by two-way ANOVA. All results were expressed as the mean \pm s.E.M., $P<0.05$ was considered significant.

\section{Results}

Effect of prenatal androgen excess on serum LH in peripubertal female rats

The morning serum LH levels did not significantly differ between the PNA groups and control groups at the ages of 4,6 , and 8 weeks ( $P>0.05$; Fig. $2 A)$. Nevertheless, the serum LH pulse frequency in 6-week-old PNA rats was significantly higher than that for the control rats $(P<0.05$;

Published by Bioscientifica Ltd 

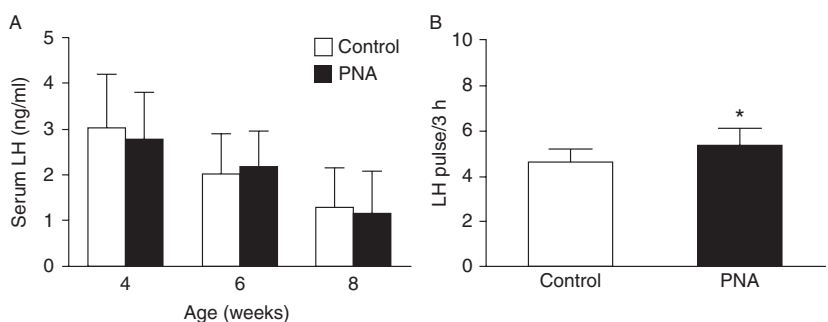

Figure 2

Effect of prenatal DHT treatment on serum $\mathrm{LH}$ release in peripubertal female rats. (A) The morning serum LH concentrations in control $(n=21)$ and prenatally androgenized (PNA) rats $(n=24)$ at postnatal weeks 4,6 , and 8 . (B) At the age of 6 weeks, blood samples were taken by jugular venipuncture every $10 \mathrm{~min}$ from 0800 to $1100 \mathrm{~h}$ and the LH pulse frequency

Fig. 2B). The amplitude of LH pulses was not significantly different between the two groups (data not shown).

\section{Effect of prenatal androgen excess on expression of hypothalamic genes in PNA rats}

PNA treatment resulted in markedly elevated mRNA levels of Kiss1 in the hypothalamus of 6- and 8-week-old PNA
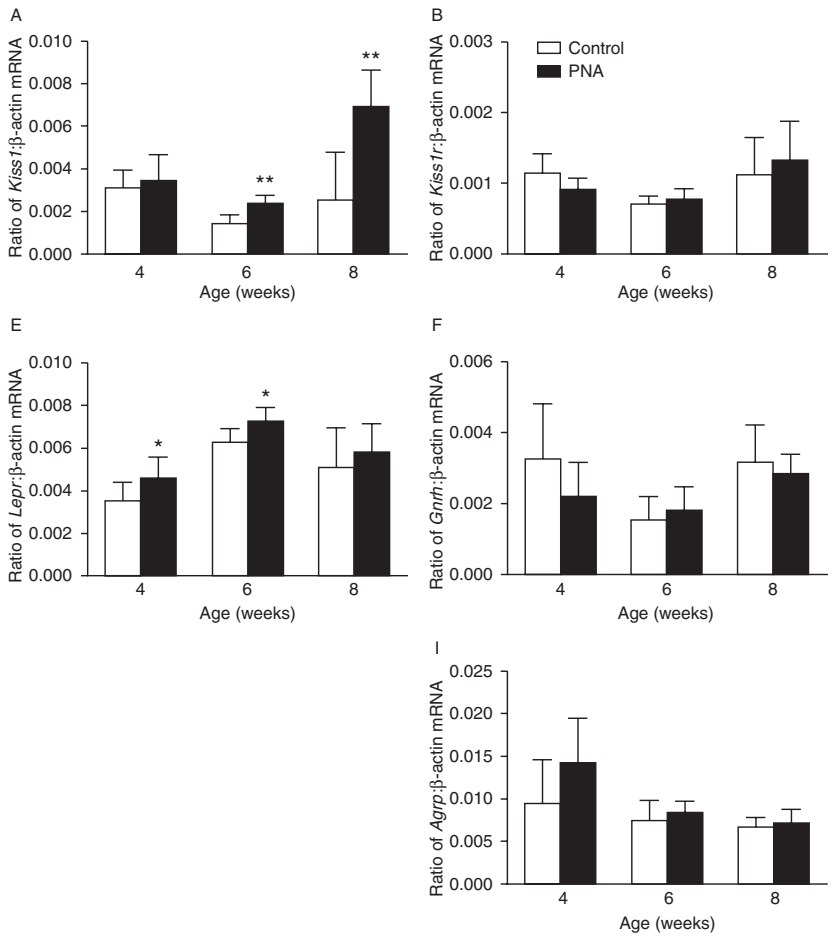

Figure 3

Effect of prenatal DHT treatment on the hypothalamic genes expression in peripubertal female rats. The values represent mRNA expression levels of (A) Kiss1, (B) Kiss1r, (C) Nkb, (D) Nk3r, (E) Obrb, (F) Gnrh, (G) Npy, (H) Npyr, (I) Agrp, and (J) Pomc in the hypothalamus of control $(n=18)$ and
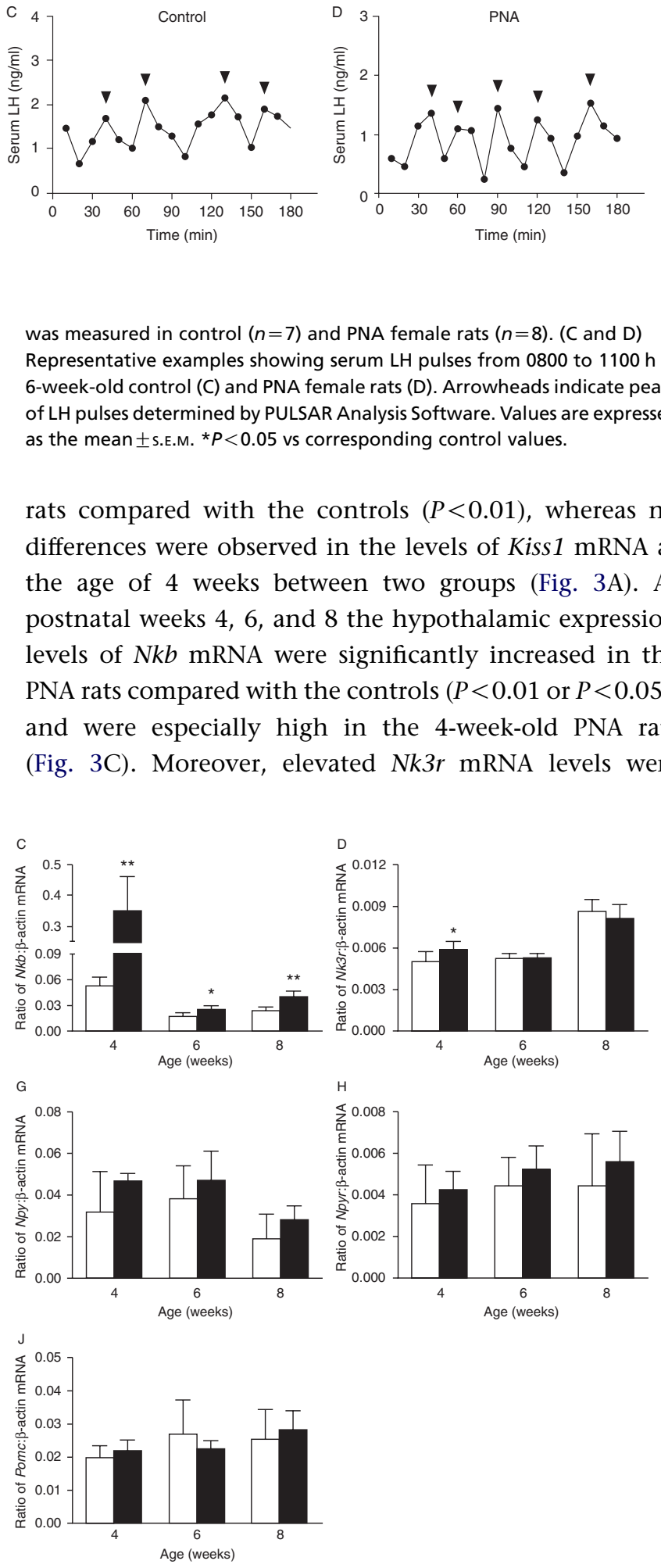

was measured in control $(n=7)$ and PNA female rats $(n=8)$. (C and D) Representative examples showing serum LH pulses from 0800 to $1100 \mathrm{~h}$ in 6-week-old control (C) and PNA female rats (D). Arrowheads indicate peaks of LH pulses determined by PULSAR Analysis Software. Values are expressed as the mean \pm s.E.M. ${ }^{*} P<0.05$ vs corresponding control values.

rats compared with the controls $(P<0.01)$, whereas no differences were observed in the levels of Kiss1 mRNA at the age of 4 weeks between two groups (Fig. 3A). At postnatal weeks 4,6 , and 8 the hypothalamic expression levels of $N k b$ mRNA were significantly increased in the PNA rats compared with the controls $(P<0.01$ or $P<0.05)$, and were especially high in the 4-week-old PNA rats (Fig. 3C). Moreover, elevated $N k 3 r$ mRNA levels were

prenatally androgenized (PNA) rats $(n=18)$ at postnatal 4,6 , and 8 weeks. Values are expressed as the mean \pm s.E.M. ${ }^{*} P<0.05$ and $* * P<0.01$ vs corresponding control values.

Published by Bioscientifica Ltd. 
detected in the hypothalamus of PNA rats at postnatal 4 weeks $(P<0.05$; Fig. 3D). The 4 - and 6-week-old PNA rats had significantly increased Lepr mRNA levels in the hypothalamus compared with the controls $(P<0.05)$, whereas the 8-week-old PNA rats did not show altered Lepr mRNA levels (Fig. 3E). No differences were observed in the mRNA levels of Kiss1r, Gnrh, Npy, Npyr, Agrp, and Pomc between two groups at any development stage $(P>0.05$; Fig. 3B, F, G, H, I and J).

\section{Coexpression of kisspeptin/LEPR and NKB/LEPR in the hypothalamic ARC of pubertal PNA rats}

The colocalization of kisspeptin/LEPR and NKB/LEPR in the ARC of 6-week-old PNA rats was observed using double-label immunofluorescence. A cluster of cell bodies with kisspeptin immunoreactivity were detected in the $\mathrm{ARC}$, with more kisspeptin-positive neurons per section in the caudal region than in the middle and rostral region of this nucleus. In the caudal ARC, nearly $90 \%$ of kisspeptinpositive neurons coexpressed LEPR (Fig. 4A, B and C). Moreover, numerous NKB-immunoreactive neurons were also observed in the caudal ARC of 6-week-old PNA rats. LEPR immunoreactivity was detected in some
NKB-containing cells; the percentage of NKB neurons expressing LEPR was $\sim 70 \%$ (Fig. 4D, E and F). Double labeling of kisspeptin/NKB and leptin receptor by immunofluorescence revealed that all three substances were concomitantly expressed in the ARC of pubertal PNA rats.

\section{Actions of kisspeptin, senktide, and leptin upon LH secretion in pubertal PNA rats}

After i.c.v. injection of kisspeptin, LH levels at 15, 30, and 60 min were significantly higher in both the 6-week-old PNA group and the control group compared with vehicle control group $(P<0.01$ or $P<0.05$; Fig. $5 A$ and $B)$. In particular, the PNA and control rats displayed five- and threefold increases in circulating LH levels at 60 min after administration of kisspeptin respectively. Senktide, the NK3R agonist, induced a robust increase in serum LH levels at 15, 30, and 60 min after central administration in 6-week-old PNA rats $(P<0.01$ or $P<0.05$; Fig. $5 \mathrm{E})$. In the control group, LH levels at 15 and 30 min were markedly elevated after injection of senktide $(P<0.01$ or $P<0.05)$, whereas LH levels at $60 \mathrm{~min}$ decreased and were not significantly different from those for animals that received the vehicle (Fig. 5D). The 6-week-old PNA rats treated with
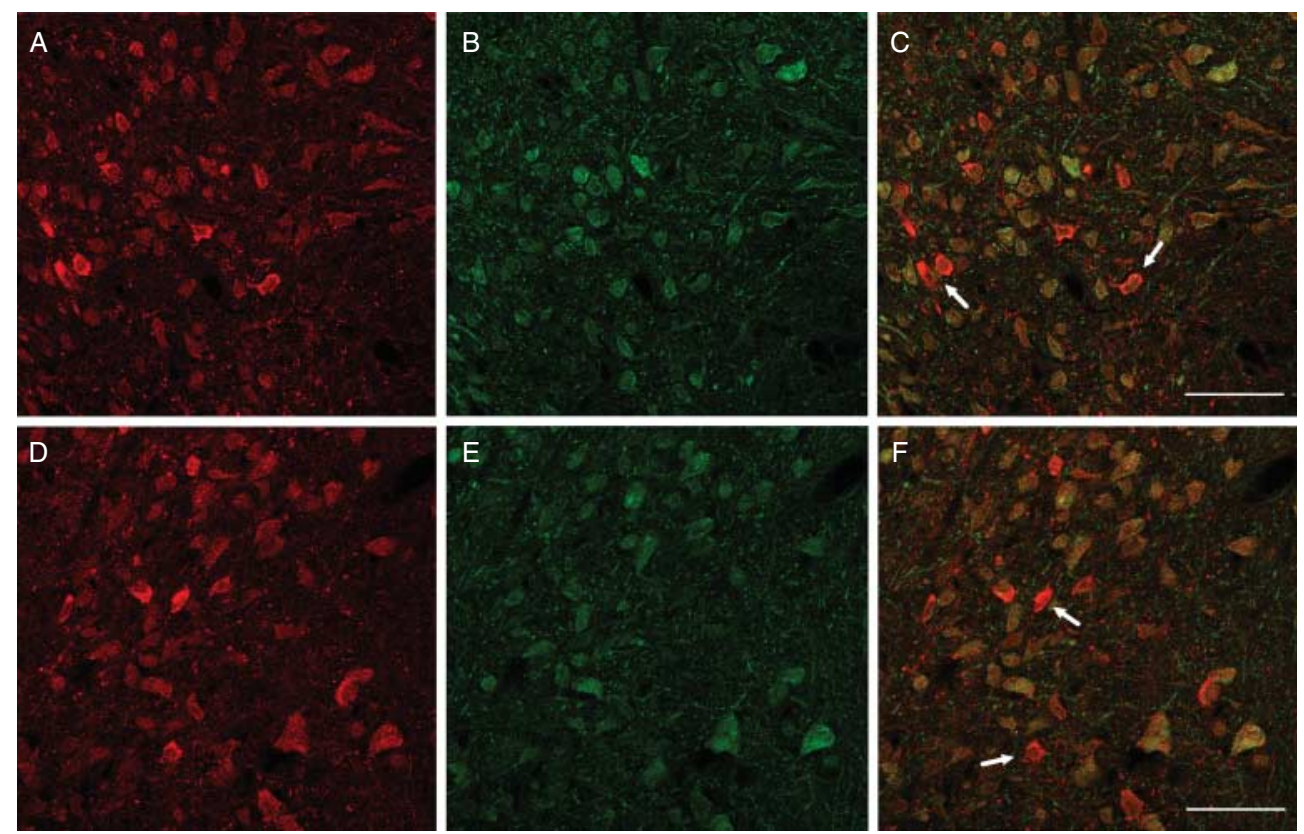

\section{Figure 4}

Coexpression of kisspeptin/LEPR and neurokinin B (NKB)/LEPR in the hypothalamic arcuate nucleus (ARC) of prenatally androgenized (PNA) rats. Confocal microscopic images of sections stained by double-label immunofluorescence for kisspeptin ( $A$, red), NKB (D, red), and LEPR (B and E, green) in the caudal ARC of 6 -week-old PNA rats. ( $C$ and F) Computer-aided merged images of $A$ and $B$ and of $D$ and $E$ respectively. The arrows in (C) indicate certain cell bodies containing kisspeptin immunoreactivity, but not LEPR. The arrows in (F) show exclusively NKB-immunoreactive cell bodies. Scale bars represent $50 \mu \mathrm{m}$. http://joe.endocrinology-journals.org DOI: 10.1530/JOE-14-0021
() 2014 Society for Endocrinology Printed in Great Britain
Published by Bioscientifica Ltd. 

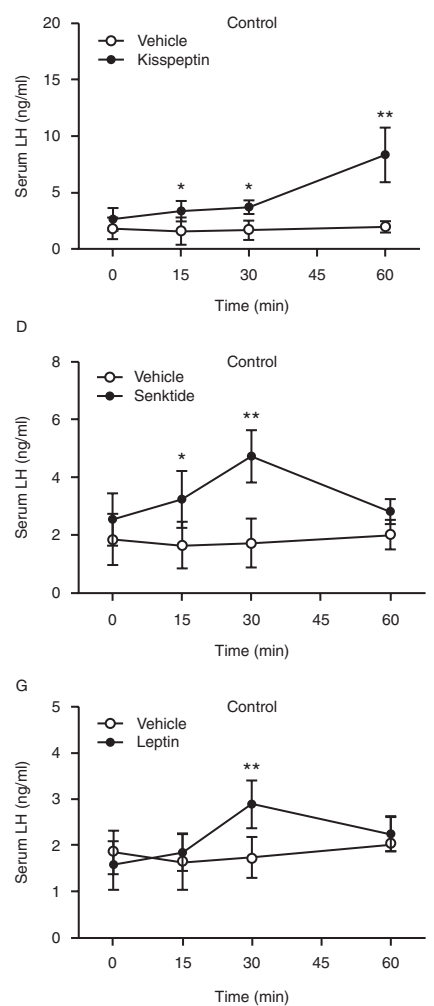
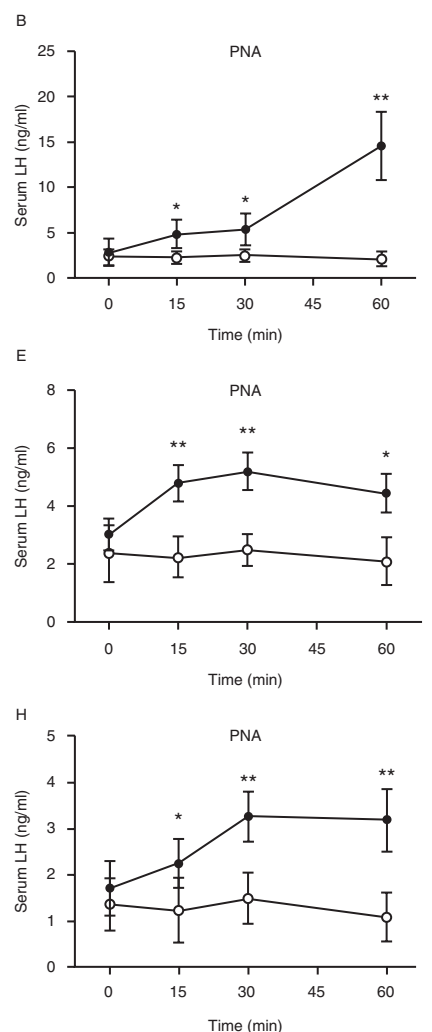

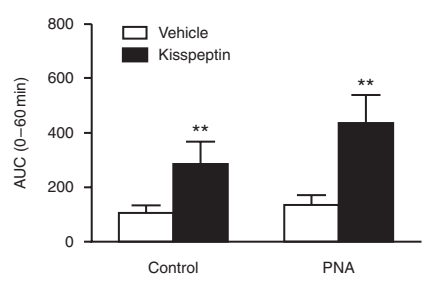

F
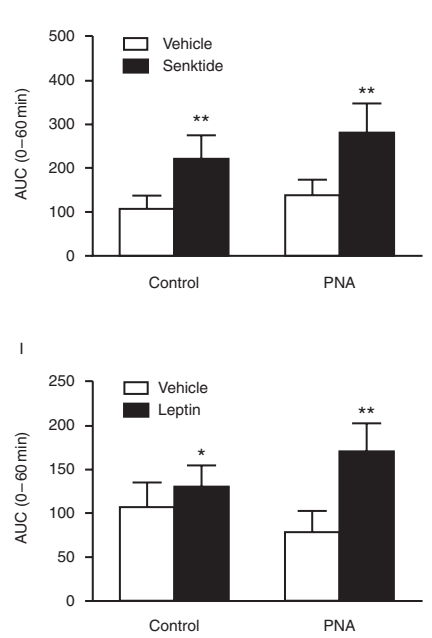

Figure 5

Effects of central administration of kisspeptin, senktide, and leptin on LH secretion in the 6 -week-old female rats. Kisspeptin $(1 \mathrm{nmol} / 10 \mu \mathrm{l})$, senktide $(600 \mathrm{pmol} / 10 \mu \mathrm{l})$, leptin $(1 \mathrm{nmol} / 10 \mu \mathrm{l})$, or saline $(10 \mu \mathrm{l}$, vehicle) were acutely injected into the lateral cerebral ventricle of 6-week-old prenatally androgenized (PNA) and control rats, and blood samples were collected by jugular venipuncture before ( $0 \mathrm{~min}$ ) and 15,30 , and $60 \mathrm{~min}$ after administration. ( $A$ and $B$ ) The serum $\mathrm{LH}$ levels after central injection of kisspeptin or vehicle in control $(\mathrm{A} ; n=16)$ and PNA rats $(\mathrm{B} ; n=16)$. (D and $\mathrm{E})$ The serum LH levels after central injection of senktide or vehicle in control (D; $n=16)$ and PNA rats (E; $n=16)$. (G and H) The serum LH levels after central injection of leptin or vehicle in control $(G ; n=16)$ and PNA rats $(H$; $n=16)$. (C, F, and I) Corresponding 0 - to 60-min area under the curve (AUC) values for control and PNA rats. Values are expressed as the mean \pm s.E.M. ${ }^{*} P<0.05$ and $* * P<0.01$ vs corresponding control values.

and B). Likewise, the mRNA levels of Kiss1 and Lepr were not significantly different between senktide treatment groups and vehicle groups $(P>0.05$; Fig. $6 \mathrm{C}$ and D). An increasing trend in hypothalamic Kiss1 mRNA levels was observed in the animals treated with senktide, although it did not reach statistical significance (Fig. 6C). In both the 6-week-old PNA rats and the control rats, the hypothalamic Kiss1 mRNA levels increased markedly after leptin administration $(P<0.01$; Fig. 6E), whereas the levels of $N k b$ mRNA did not differ between the leptin groups and the vehicle groups (Fig. 6F).

\section{Effect of leptin on serum LH secretion following pretreatment with a kisspeptin antagonist in pubertal PNA rats}

On the basis of the stimulatory effects of leptin on LH secretion and hypothalamic Kiss1 mRNA levels in pubertal http://joe.endocrinology-journals.org DOI: 10.1530/JOE-14-0021
C 2014 Society for Endocrinology Printed in Great Britain 

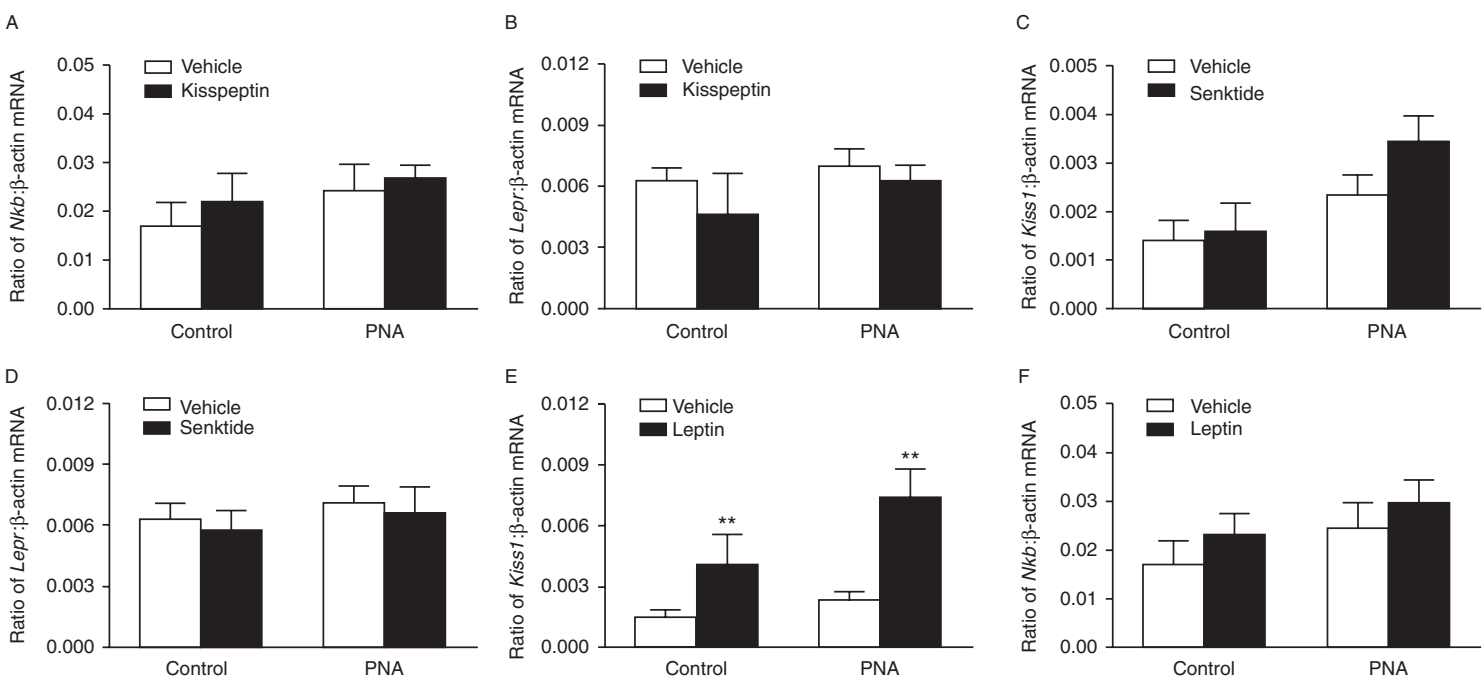

Figure 6

Effects of central administration of kisspeptin, senktide, and leptin on expression of hypothalamic genes in 6-week-old female rats. ( $A$ and $B$ ) The values represent expression levels of $N k b(A)$ and Lepr (B) mRNAs in the hypothalamus of control $(n=6)$ and prenatally androgenized (PNA) rats $(n=6)$ after treatment with kisspeptin or vehicle. (C and D) The values represent the expression levels of Kiss1 (C) and Lepr (D) mRNAs in the

PNA rats, we next sought to determine whether leptin stimulates LH secretion indirectly by activating the ARC kisspeptin neurons. In 6-week-old PNA rats, i.c.v. administration of kisspeptin-234 resulted in a suppression of LH secretion (Fig. 7A). Nevertheless, pretreatment with kisspeptin-234 failed to suppress the elevated serum LH levels stimulated by leptin (Fig. 7C). In the group treated with kisspeptin-234 and leptin, the AUC values for the 60-min posttreatment period were significantly higher than those for the 60-min baseline control period $(P<0.01$; Fig. 7D). No difference was observed in the $60-$ min posttreatment AUC values between the treatment group and the positive control group $(P>0.05)$.

\section{Discussion}

In this study, we investigated the effect of prenatal androgen exposure on $\mathrm{LH}$ secretion in female rats during the peripubertal period. The morning serum LH levels did not significantly differ between the PNA groups and control groups at postnatal weeks 4, 6, and 8. Moreover, we observed the serum LH concentrations every $10 \mathrm{~min}$ for $3 \mathrm{~h}$ and found that the 6-week-old PNA rats exhibited increased LH pulse frequency. In previous studies, hyperandrogenemic girls with PCOS exhibited elevated concentrations of serum LH, accompanied by an increase in pulse frequency and amplitude (van Hooff et al. 2000). hypothalamus of control $(n=6)$ and PNA rats $(n=6)$ after treatment with senktide or vehicle. ( $E$ and $F$ ) The values represent expression levels of Kiss1 (E) and $N k b$ (F) mRNAs in the hypothalamus of control $(n=6)$ and PNA rats $(n=6)$ after treatment with leptin or vehicle. Values are expressed as the mean \pm S.E.M. ${ }^{*} P<0.01$ vs corresponding control values.

Animal models have shown that prenatal androgen treatment induce accelerations of $\mathrm{LH}$ pulsatile release in primates (Abbott et al. 2009), sheep (Forsdike et al. 2007, Steckler et al. 2009), and rodents (Foecking et al. 2005), in accordance with the present results. Our observations confirm the concept that an early disturbance due to intrauterine androgen excess reprograms nervous tissue development of the fetus and irreversibly alters neuroendocrine function in female offspring.

On the basis of the functional role of kisspeptin and $\mathrm{NKB}$ in the mediation of the GNRH pulse generator in the ARC, we speculated that alterations in these neuropeptides may be associated with the higher LH pulse frequency in PNA female rats. In accordance with this prediction, we found that hypothalamic Kiss1 mRNA levels were markedly elevated in the 6- and 8-week-old PNA rats compared with controls. Our data indicated that prenatal treatment with DHT induced increased Kiss1 mRNA expression in the hypothalamus of PNA rats after the onset of puberty and that the hypothalamic kisspeptin population may be involved in higher LH pulse frequency at puberty. It has been reported that Kiss1 and Gpr54 knockout mice failed to go through puberty at the correct time; however, some studies showed evidence of gonadotropic activity after several months (Chan et al. 2009, Colledge 2009), raising the possibility that other neural components within the GNRH neuronal network may 

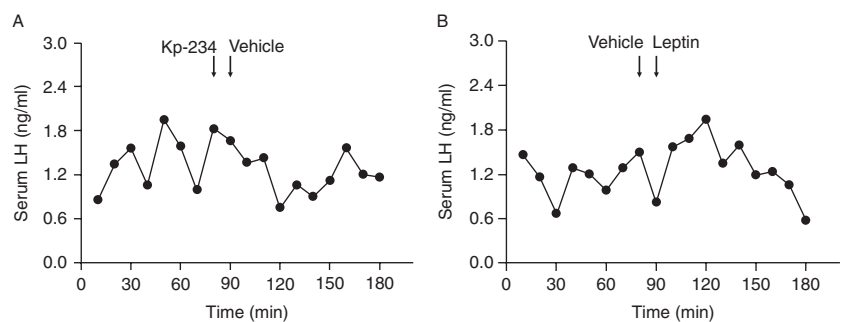

Figure 7

Effect of leptin on LH secretion following pretreatment with a kisspeptin receptor antagonist (Kp-234) in prenatally androgenized (PNA) female rats. Representative LH profiles indicating the effect of i.c.v. injection of (A) $\mathrm{Kp}-234$ + vehicle, (B) vehicle + leptin, or (C) Kp-234 + leptin on LH secretion in the 6-week-old PNA rats. The arrows indicate central administration. (A) Central injection of $\mathrm{Kp}-234$ resulted in suppression of $\mathrm{LH}$ secretion. (B) The levels of serum LH markedly increased after central injection of

partly replace kisspeptin-GPR54 signaling. Our study demonstrated that, at postnatal weeks 4,6 , and 8 the hypothalamic expression levels of $N k b$ mRNA in PNA rats were significantly elevated compared with the levels for controls and were especially high in the 4-week-old PNA rats. Moreover, the increased Nk3r mRNA levels were also detected in the hypothalamus of 4-week-old PNA rats. On the basis of these observations, we speculated that intrauterine androgen exposure resulted in the increased hypothalamic $N k b$ and $N k 3 r$ mRNA levels in PNA rats before puberty and NKB-NK3R signaling may be essential for the activation of GNRH neurons and increased $\mathrm{LH}$ pulse frequency at the peripubertal stage. These findings provide evidence that prenatal androgen treatment induces differential changes in the expression of several genes involved in the mediation of GNRH/LH pulsatile release in peripubertal PNA rats. Nevertheless, our observations differ from those reported by some studies in animal models. In another study of rats, DHT treatment had no effect on Kiss1 mRNA in the hypothalamus; however, it significantly elevated Kiss1 mRNA levels in pituitary tissue, ovary, and adipose tissue (Brown et al. 2009). A study on female sheep found that prenatal androgen treatment resulted in a reduction by half of the number of NKB cells, whereas the number of kisspeptin cells remained at levels similar to those in the KNDy subpopulation of control females (Cheng et al. 2010). The conflicting observations in these studies may result from differences between the action of DHT and testosterone, different neuron populations, species differences, and different age/sex groupings.

In this study, to investigate whether kisspeptin and $\mathrm{NKB}$ are involved in the activation of GNRH neurons and
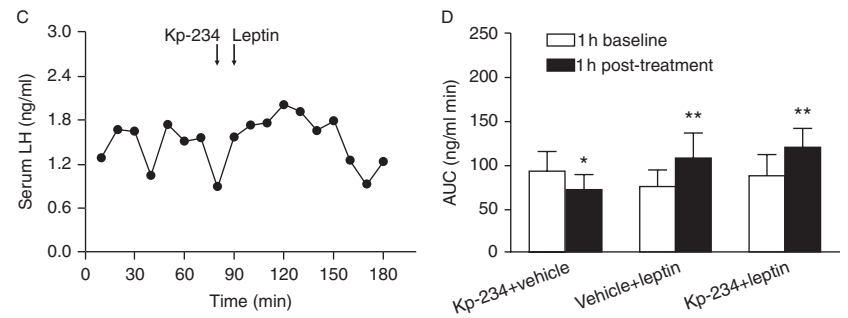

leptin. (C) Pretreatment with Kp-234 failed to suppress the elevated serum LH levels stimulated by leptin. (D) Area under the curve (AUC) values for the 60-min pretreatment period (baseline) and the 60-min posttreatment period are compared in the experiment summary. Kp-234, kisspeptin-234. Values are expressed as the mean \pm S.E.M., $n=22$. ${ }^{\star} P<0.05$ and $* * P<0.01$ vs 60 -min baseline control period within the same treatment group.

the increased LH pulse frequency in PNA rats, we evaluated the serum LH concentrations in 6-week-old female rats after central administration of kisspeptin and senktide. After injection of kisspeptin, LH levels at 15-, 30-, and 60-min were significantly higher in both the 6-week-old PNA group and the control group compared with levels for groups that received an injection of vehicle. In particular, the PNA and control rats displayed five- and threefold increases in circulating LH levels at $60 \mathrm{~min}$ after kisspeptin treatment respectively. These findings demonstrated that exogenous kisspeptin provided tonic drive to GNRH neurons and potently increased LH secretion in pubertal female rats. Our observations are consistent with the findings reported for other studies in animal models. In primates, repetitive administration of kisspeptin increased plasma LH levels before puberty (Shahab et al. 2005, Plant et al. 2006). Moreover, kisspeptin administration potently activated GNRH neurons in the rodent (Han et al. 2005, Dumalska et al. 2008, Pielecka-Fortuna et al. 2008) and induced GNRH secretion in the ewe (Messager et al. 2005).

We also found that senktide elicited a robust increase in serum LH levels at 15 and 30 min after central administration and LH levels at $60 \mathrm{~min}$ remained significantly elevated in 6-week-old PNA rats. In the control group, $\mathrm{LH}$ levels at 15 and $30 \mathrm{~min}$ were markedly elevated after injection of senktide, whereas at $60 \mathrm{~min}$ LH levels had decreased and were not significantly different from those for the vehicle group. Our data demonstrated that exogenous NK3R agonist exerted robust stimulation of GNRH neurons and a prolonged increase in LH concentrations in pubertal female rats, and senktide was more efficacious at stimulating LH release in the PNA group than in the control group. To date, the pharmacological actions

Published by Bioscientifica Ltd. 
of NKB on the regulation of pulsatile GNRH/LH secretion remain controversial. The central administration of senktide markedly decreased serum LH levels in ovariectomized rats treated with low levels of estradiol (Sandoval-Guzman $\&$ Rance 2004). Inhibitory effects on LH release were also observed after central injection of either NKB or senktide in ovariectomized goats (Wakabayashi et al. 2010) and mice (Navarro et al. 2009). In contrast, activation of NK3R with senktide consistently stimulated LH secretion in ewes during the follicular phase (Billings et al. 2010). In prepubertal rhesus monkeys, stimulation of LH secretion was observed after i.v. infusion of either NKB or senktide (Ramaswamy et al. 2010). These paradoxical observations may be explained by species differences in the efficacy of pharmacological agents and in the location of NK3R, as well as the gonadal status of animal models. The steroid environment may alter the basal activity of the neurons, the relative levels of gene expression, and the number or responsiveness of receptors (Rance et al. 2010).

Studies showed that i.c.v. coadministration of NKB and kisspeptin amplified kisspeptin's stimulatory effects in male rodents, whereas coadministration of NKB and kisspeptin to mouse hypothalamic explants inhibited kisspeptin's positive effect on GNRH release, indicating that NKB modulates the effect of kisspeptin on LH secretion, and that the pharmacological actions of NKB or senktide are complicated (Corander et al. 2010, Rance et al. 2010). On the basis of further observations, researchers have speculated that NKB is the trigger that initiates synchronous firing of KNDy neurons, and that kisspeptin in KNDy cells is the output that drives GNRH pulses (Lehman et al. 2010). In this study, after central injection of senktide, an increasing trend in hypothalamic Kiss1 mRNA levels was observed in the 6-week-old PNA rats, although it did not reach statistical significance. We also found that the hypothalamic expression of $N k b$ mRNA in PNA rats increased markedly before puberty and remained high during the pubertal stage, whereas increased Kiss1 mRNA levels in the hypothalamus were observed only after the onset of puberty. Therefore, it is reasonable to infer that NKB signaling has an integral role in the activation of GNRH neurons and initiation of increased LH pulse frequency during peripubertal development stage in PNA rats, and that the hypothalamic kisspeptin population may coordinate NKB's stimulatory effects on LH release.

Leptin, an important adipokine, has an indirect interaction with GNRH neurons (Quennell et al. 2009, Louis et al. 2011). Recent findings have indicated that leptin receptors were expressed in ARC kisspeptin neurons at a modest level (Cravo et al. 2011). Nevertheless, conditional transgenic deletion of leptin revealed that the direct action of leptin on kisspeptin neuron did not appear to be required for fertility or pubertal maturation (Donato et al. 2011). In this study, the 4- and 6-week-old PNA rats had significantly increased Lepr mRNA levels in the hypothalamus compared with control rats. We also found that kisspeptin- and NKBpositive cells coexpressed leptin receptors in the ARC of PNA rats. To determine whether the interaction of kisspeptin, $\mathrm{NKB}$, and leptin was responsible for the increased LH pulse frequency in pubertal PNA rats, we quantified the levels of Kiss1 and Nkb mRNAs in the hypothalamus of 6-week-old PNA rats after central administration of leptin. The results indicated that leptin upregulated Kiss1 mRNA expression in PNA rats; however, pretreatment with a kisspeptin antagonist failed to suppress the elevated serum LH stimulated by leptin. On the basis of these observations, we speculated that the stimulatory effects of leptin may be conveyed indirectly to GNRH neurons via other neural components within the GNRH neuronal network, rather than through the kisspeptin-GPR54 pathway. It has been proposed that the effect of leptin on impaired regulation of the hypothalamic-pituitary-gonadal axis may be involved in the pathogenesis of PCOS (Blüher \& Mantzoros 2007). In previous studies, we observed that pubertal PNA female rats exhibited hyperleptinemia (Yan et al. 2013). These findings indicated that hyperleptinemia at puberty may participate indirectly in the stimulation of the GNRH pulse generator and initiation of rapid LH pulsatile release in PNA rats.

In summary, prenatal androgen exposure induced elevated LH pulse frequency in pubertal female rats. The hypothalamic expression of $N k b$ and Lepr mRNAs in PNA rats were markedly increased before puberty and remained high during the pubertal stage, whereas increased Kiss1 mRNA levels were detected only after the onset of puberty. Exogenous kisspeptin, NK3R agonist, and leptin exerted tonic stimulation of LH secretion in the 6-week-old PNA rats. Leptin upregulated Kiss1 mRNA expression in pubertal PNA rats; however, pretreatment with a kisspeptin antagonist failed to suppress the elevated serum LH stimulated by leptin. On the basis of these results, we speculated that $\mathrm{NKB}$ and leptin play an essential role in the activation of GNRH neurons and initiation of increased LH pulse frequency in PNA female rats at puberty and kisspeptin may coordinate their stimulatory effects on LH release.

\section{Declaration of interest}

The authors declare that there is no conflict of interest that could be perceived as prejudicing the impartiality of the research reported.

Published by Bioscientifica Ltd. 


\section{Funding}

This work was supported by the 973 Program of China (grant numbers 2012CB944902 and 2012CB944703) and the Jiangsu programs of China (grant numbers BL2012009, BM2013058, and PAPD).

\section{References}

Abbott DH, Tarantal AF \& Dumesic DA 2009 Fetal, infant, adolescent and adult phenotypes of polycystic ovary syndrome in prenatally androgenized female rhesus monkeys. American Journal of Primatology $\mathbf{7 1}$ 776-784. (doi:10.1002/ajp.20679)

Billings HJ, Connors JM, Altman SN, Hileman SM, Holaskova I, Lehman MN, McManus CJ, Nestor CC, Jacobs BH \& Goodman RL 2010 Neurokinin B acts via the neurokinin-3 receptor in the retrochiasmatic area to stimulate luteinizing hormone secretion in sheep. Endocrinology 151 3836-3846. (doi:10.1210/en.2010-0174)

Blüher S \& Mantzoros CS 2007 Leptin in reproduction. Current Opinion in Endocrinology, Diabetes, and Obesity 14 458-464. (doi:10.1097/MED. 0b013e3282f1cfdc)

Broder-Fingert S, Shah B, Kessler M, Pawelczak M \& David R 2009 Evaluation of adolescents for polycystic ovary syndrome in an urban population. Journal of Clinical Research in Pediatric Endocrinology 1 188-193. (doi:10. 4008/jcrpe.v1i4.50)

Brown R, Wilkinson D, Imran S \& Wilkinson M 2009 Dihydrotestosterone increases Kiss 1 expression in adipose and pituitary tissue, but not in hypothalamus, in a rat model of polycystic ovary syndrome (PCOS). Endocrine Abstracts 19287.

Burt Solorzano CM, McCartney CR, Blank SK, Knudsen KL \& Marshall JC 2010 Hyperandrogenaemia in adolescent girls: origins of abnormal gonadotropin-releasing hormone secretion. BJOG: an International Journal of Obstetrics and Gynaecology 117 143-149. (doi:10.1111/j. 1471-0528.2009.02383.x)

Castellano JM, Navarro VM, Fernandez-Fernandez R, Roa J, Vigo E, Pineda R, Dieguez C, Aguilar E, Pinilla L \& Tena-Sempere M 2006 Expression of hypothalamic KiSS-1 system and rescue of defective gonadotropic responses by kisspeptin in streptozotocin-induced diabetic male rats. Diabetes 55 2602-2610. (doi:10.2337/db05-1584)

Castellano JM, Navarro VM, Roa J, Pineda R, Sanchez-Garrido MA, GarciaGaliano D, Vigo E, Dieguez C, Aguilar E, Pinilla L et al. 2009 Alterations in hypothalamic KiSS-1 system in experimental diabetes: early changes and functional consequences. Endocrinology 150 784-794. (doi:10.1210/en.2008-0849)

Chan YM, Broder-Fingert S \& Seminara SB 2009 Reproductive functions of kisspeptin and Gpr54 across the life cycle of mice and men. Peptides 30 42-48. (doi:10.1016/j.peptides.2008.06.015)

Cheng G, Coolen LM, Padmanabhan V, Goodman RL \& Lehman MN 2010 The kisspeptin/neurokinin B/dynorphin (KNDy) cell population of the arcuate nucleus: sex differences and effects of prenatal testosterone in sheep. Endocrinology 151 301-311. (doi:10.1210/en.2009-0541)

Clarkson J, Han SK, Liu XH, Lee K \& Herbison AE 2010 Neurobiological mechanisms underlying kisspeptin activation of gonadotropinreleasing hormone $(\mathrm{GnRH})$ neurons at puberty. Molecular and Cellular Endocrinology 324 45-50. (doi:10.1016/j.mce.2010.01.026)

Colledge WH 2009 Transgenic mouse models to study Gpr54/kisspeptin physiology. Peptides 30 34-41. (doi:10.1016/j.peptides.2008.05.006)

Corander MP, Challis BG, Thompson EL, Jovanovic Z, Loraine Tung YC, Rimmington D, Huhtaniemi IT, Murphy KG, Topaloglu AK, Yeo GS et al. 2010 The effects of neurokinin B upon gonadotrophin release in male rodents. Journal of Neuroendocrinology 22 181-187. (doi:10.1111/ j.1365-2826.2009.01951.x)

Cravo RM, Margatho LO, Osborne-Lawrence S, Donato J Jr, Atkin S, Bookout AL, Rovinsky S, Frazao R, Lee CE, Gautron L et al. 2011 Characterization of Kiss1 neurons using transgenic mouse models. Neuroscience 173 37-56. (doi:10.1016/j.neuroscience.2010.11.022)

http://joe.endocrinology-journals.org DOI: 10.1530/JOE-14-0021
() 2014 Society for Endocrinology Printed in Great Britain
Donato J Jr, Cravo RM, Frazao R, Gautron L, Scott MM, Lachey J, Castro IA, Margatho LO, Lee S, Lee C et al. 2011 Leptin's effect on puberty in mice is relayed by the ventral premammillary nucleus and does not require signaling in Kiss1 neurons. Journal of Clinical Investigation 121 355-368. (doi:10.1172/JCI45106)

Dumalska I, Wu M, Morozova E, Liu R, van den Pol A \& Alreja M 2008 Excitatory effects of the puberty-initiating peptide kisspeptin and group I metabotropic glutamate receptor agonists differentiate two distinct subpopulations of gonadotropin-releasing hormone neurons. Journal of Neuroscience 28 8003-8013. (doi:10.1523/JNEUROSCI.1225-08.2008)

Foecking EM, Szabo M, Schwartz NB \& Levine JE 2005 Neuroendocrine consequences of prenatal androgen exposure in the female rat: absence of luteinizing hormone surges, suppression of progesterone receptor gene expression, and acceleration of the gonadotropin-releasing hormone pulse generator. Biology of Reproduction 72 1475-1483. (doi:10.1095/biolreprod.105.039800)

Forsdike RA, Hardy K, Bull L, Stark J, Webber LJ, Stubbs S, Robinson JE \& Franks S 2007 Disordered follicle development in ovaries of prenatally androgenized ewes. Journal of Endocrinology 192 421-428. (doi:10.1677/ joe.1.07097)

Franks S 2012 Animal models and the developmental origins of polycystic ovary syndrome: increasing evidence for the role of androgens in programming reproductive and metabolic dysfunction. Endocrinology 153 2536-2538. (doi:10.1210/en.2012-1366)

Goodman RL, Lehman MN, Smith JT, Coolen LM, de Oliveira CV, Jafarzadehshirazi MR, Pereira A, Iqbal J, Caraty A, Ciofi P et al. 2007 Kisspeptin neurons in the arcuate nucleus of the ewe express both dynorphin a and neurokinin B. Endocrinology 148 5752-5760. (doi:10.1210/en.2007-0961)

Guran T, Tolhurst G, Bereket A, Rocha N, Porter K, Turan S, Gribble FM, Kotan LD, Akcay T, Atay Z et al. 2009 Hypogonadotropic hypogonadism due to a novel missense mutation in the first extracellular loop of the neurokinin B receptor. Journal of Clinical Endocrinology and Metabolism 94 3633-3639. (doi:10.1210/jc.2009-0551)

Han SK, Gottsch ML, Lee KJ, Popa SM, Smith JT, Jakawich SK, Clifton DK, Steiner RA \& Herbison AE 2005 Activation of gonadotropin-releasing hormone neurons by kisspeptin as a neuroendocrine switch for the onset of puberty. Journal of Neuroscience 25 11349-11356. (doi:10.1523/ JNEUROSCI.3328-05.2005)

van Hooff MH, Voorhorst FJ, Kaptein MB, Hirasing RA, Koppenaal C \& Schoemaker J 2000 Polycystic ovaries in adolescents and the relationship with menstrual cycle patterns, luteinizing hormone, androgens, and insulin. Fertility and Sterility 74 49-58. (doi:10.1016/S00150282(00)00584-7)

Huang J, Ni R, Chen X, Huang L, Mo Y \& Yang D 2010 Metabolic abnormalities in adolescents with polycystic ovary syndrome in south China. Reproductive Biology and Endocrinology 8 142. (doi:10.1186/ 1477-7827-8-142)

Lehman MN, Coolen LM \& Goodman RL 2010 Minireview: Kisspeptin/ neurokinin B/dynorphin (KNDy) cells of the arcuate nucleus: a central node in the control of gonadotropin-releasing hormone secretion. Endocrinology 151 3479-3489. (doi:10.1210/en.2010-0022)

Li M, Xue K, Ling J, Diao FY, Cui YG \& Liu JY 2010 The orphan nuclear receptor NR4A1 regulates transcription of key steroidogenic enzymes in ovarian theca cells. Molecular and Cellular Endocrinology 319 39-46. (doi:10.1016/j.mce.2010.01.014)

Louis GW, Greenwald-Yarnell M, Phillips R, Coolen LM, Lehman MN \& Myers MG Jr 2011 Molecular mapping of the neural pathways linking leptin to the neuroendocrine reproductive axis. Endocrinology 152 2302-2310. (doi:10.1210/en.2011-0096)

Messager S, Chatzidaki EE, Ma D, Hendrick AG, Zahn D, Dixon J, Thresher RR, Malinge I, Lomet D, Carlton MB et al. 2005 Kisspeptin directly stimulates gonadotropin-releasing hormone release via $\mathrm{G}$ proteincoupled receptor 54. PNAS 102 1761-1766. (doi:10.1073/ pnas.0409330102) 
Mostari P, Ieda N, Deura C, Minabe S, Yamada S, Uenoyama Y, Maeda K \& Tsukamura H 2013 Dynorphin-к opioid receptor signaling partly mediates estrogen negative feedback effect on LH pulses in female rats. Journal of Reproduction and Development 59 266-272. (doi:10.1262/ jrd.2012-193)

Navarro VM, Fernandez-Fernandez R, Castellano JM, Roa J, Mayen A, Barreiro ML, Gaytan F, Aguilar E, Pinilla L, Dieguez C et al. 2004 Advanced vaginal opening and precocious activation of the reproductive axis by KiSS-1 peptide, the endogenous ligand of GPR54. Journal of Physiology 561 379-386. (doi:10.1113/jphysiol.2004.072298)

Navarro VM, Gottsch ML, Chavkin C, Okamura H, Clifton DK \& Steiner RA 2009 Regulation of gonadotropin-releasing hormone secretion by kisspeptin/dynorphin/neurokinin B neurons in the arcuate nucleus of the mouse. Journal of Neuroscience 29 11859-11866. (doi:10.1523/ JNEUROSCI.1569-09.2009)

Navarro VM, Ruiz-Pino F, Sanchez-Garrido MA, Garcia-Galiano D, Hobbs SJ, Manfredi-Lozano M, Leon S, Sangiao-Alvarellos S, Castellano JM, Clifton DK et al. 2012 Role of neurokinin B in the control of female puberty and its modulation by metabolic status. Journal of Neuroscience 32 2388-2397. (doi:10.1523/JNEUROSCI.4288-11.2012)

Pielecka-Fortuna J, Chu Z \& Moenter SM 2008 Kisspeptin acts directly and indirectly to increase gonadotropin-releasing hormone neuron activity and its effects are modulated by estradiol. Endocrinology 149 1979-1986. (doi:10.1210/en.2007-1365)

Plant TM, Ramaswamy S \& Dipietro MJ 2006 Repetitive activation of hypothalamic $\mathrm{G}$ protein-coupled receptor 54 with intravenous pulses of kisspeptin in the juvenile monkey (Macaca mulatta) elicits a sustained train of gonadotropin-releasing hormone discharges. Endocrinology 147 1007-1013. (doi:10.1210/en.2005-1261)

Quennell JH, Mulligan AC, Tups A, Liu X, Phipps SJ, Kemp CJ, Herbison AE, Grattan DR \& Anderson GM 2009 Leptin indirectly regulates gonadotropin-releasing hormone neuronal function. Endocrinology 150 2805-2812. (doi:10.1210/en.2008-1693)

Quennell JH, Howell CS, Roa J, Augustine RA, Grattan DR \& Anderson GM 2011 Leptin deficiency and diet-induced obesity reduce hypothalamic kisspeptin expression in mice. Endocrinology 152 1541-1550. (doi:10.1210/en.2010-1100)

Ramaswamy S, Seminara SB, Ali B, Ciofi P, Amin NA \& Plant TM 2010 Neurokinin B stimulates GnRH release in the male monkey (Macaca mulatta) and is colocalized with kisspeptin in the arcuate nucleus. Endocrinology 151 4494-4503. (doi:10.1210/en.2010-0223)

Rance NE, Krajewski SJ, Smith MA, Cholanian M \& Dacks PA 2010 Neurokinin B and the hypothalamic regulation of reproduction. Brain Research 1364 116-128. (doi:10.1016/j.brainres.2010.08.059)

Roa J, Vigo E, Garcia-Galiano D, Castellano JM, Navarro VM, Pineda R, Dieguez C, Aguilar E, Pinilla L \& Tena-Sempere M 2008 Desensitization of gonadotropin responses to kisspeptin in the female rat: analyses of LH and FSH secretion at different developmental and metabolic states.
American Journal of Physiology. Endocrinology and Metabolism 294 E1088-E1096. (doi:10.1152/ajpendo.90240.2008)

Roland AV, Nunemaker CS, Keller SR \& Moenter SM 2010 Prenatal androgen exposure programs metabolic dysfunction in female mice. Journal of Endocrinology 207 213-223. (doi:10.1677/JOE-10-0217)

Sandoval-Guzman T \& Rance NE 2004 Central injection of senktide, an NK3 receptor agonist, or neuropeptide Y inhibits LH secretion and induces different patterns of Fos expression in the rat hypothalamus. Brain Research 1026 307-312. (doi:10.1016/j.brainres.2004.08.026)

Shahab M, Mastronardi C, Seminara SB, Crowley WF, Ojeda SR \& Plant TM 2005 Increased hypothalamic GPR54 signaling: a potential mechanism for initiation of puberty in primates. PNAS 102 2129-2134. (doi:10.1073/pnas.0409822102)

Steckler TL, Herkimer C, Dumesic DA \& Padmanabhan V 2009 Developmental programming: excess weight gain amplifies the effects of prenatal testosterone excess on reproductive cyclicity - implication for polycystic ovary syndrome. Endocrinology 150 1456-1465. (doi:10.1210/en.2008-1256)

Terasawa E \& Fernandez DL 2001 Neurobiological mechanisms of the onset of puberty in primates. Endocrine Reviews 22 111-151. (doi:10.1210/ edrv.22.1.0418)

Topaloglu AK, Reimann F, Guclu M, Yalin AS, Kotan LD, Porter KM, Serin A, Mungan NO, Cook JR, Ozbek MN et al. 2009 TAC3 and TACR3 mutations in familial hypogonadotropic hypogonadism reveal a key role for neurokinin B in the central control of reproduction. Nature Genetics 41 354-358. (doi:10.1038/ng.306)

Tyndall V, Broyde M, Sharpe R, Welsh M, Drake AJ \& McNeilly AS 2012 Effect of androgen treatment during foetal and/or neonatal life on ovarian function in prepubertal and adult rats. Reproduction 143 21-33. (doi:10.1530/REP-11-0239)

Wakabayashi Y, Nakada T, Murata K, Ohkura S, Mogi K, Navarro VM, Clifton DK, Mori Y, Tsukamura H, Maeda K et al. 2010 Neurokinin B and dynorphin $\mathrm{A}$ in kisspeptin neurons of the arcuate nucleus participate in generation of periodic oscillation of neural activity driving pulsatile gonadotropin-releasing hormone secretion in the goat. Journal of Neuroscience 30 3124-3132. (doi:10.1523/ JNEUROSCI.5848-09.2010)

Xita N \& Tsatsoulis A 2006 Review: Fetal programming of polycystic ovary syndrome by androgen excess: evidence from experimental, clinical, and genetic association studies. Journal of Clinical Endocrinology and Metabolism 91 1660-1666. (doi:10.1210/jc.2005-2757)

Yan X, Dai X, Wang J, Zhao N, Cui Y \& Liu J 2013 Prenatal androgen excess programs metabolic derangements in pubertal female rats. Journal of Endocrinology 217 119-129. (doi:10.1530/JOE-12-0577)

Young J, Bouligand J, Francou B, Raffin-Sanson ML, Gaillez S, Jeanpierre M, Grynberg M, Kamenicky P, Chanson P, Brailly-Tabard S et al. 2010 TAC3 and TACR3 defects cause hypothalamic congenital hypogonadotropic hypogonadism in humans. Journal of Clinical Endocrinology and Metabolism 95 2287-2295. (doi:10.1210/jc.2009-2600)

Received in final form 6 May 2014

Accepted 8 May 2014

Accepted Preprint published online 14 May 2014 http://joe.endocrinology-journals.org DOI: 10.1530/JOE-14-0021
() 2014 Society for Endocrinology Printed in Great Britain
Published by Bioscientifica Ltd. 